\title{
Distance Learning at University: New Challenges and Opportunities
}

\author{
Sergeeva T.L. \\ Yaroslav-the-Wise Novgorod State University, \\ Veliky Novgorod, Russia, \\ Tatyana.Sergeeva@novsu.ru
}

\author{
Reznik G.A. \\ Penza State University of Architecture and Construction, \\ Penza, Russia, \\ reznikga@gmail.com
}

\author{
Kurdova M.A. \\ Penza State University of Architecture and Construction, \\ Penza, Russia, \\ mal6200@yandex.ru
}

\begin{abstract}
Modern system of higher education has a fundamental scientific base which allows graduates to learn comprehensively, but a new era of information and globalization in education requires modernization, new approaches to organizing higher school. Combination of powerful and accessible information technologies, general computerization led to appearance of new specific educational technologies, formation of distance learning, which, in turn, allows expanding the contingent of students, integrating education into the international educational space. In recent years, distance learning has become an integral component of the educational process at higher educational institutions and is used in all forms of education. The use of distance learning allows increasing the quality of education due to the fast enrichment with the world educational resources. Distance learning becomes especially relevant in the conditions of new federal state educational standards which aimed at reducing the volume of classroom hours and increasing the proportion of students' independent work. In addition, the world coronavirus pandemic served as a kind of impetus for the development of information educational technologies. However, even those educational institutions that had actively used educational technologies in the educational process long before the arisen changes faced a number of difficulties. In the article special features of introducing distance learning into educational institutions of Russia are considered. An analysis of the state of the Russian online education market is presented. An overview of modern educational platforms which manifest themselves in the best way in the system of higher education is offered. In addition, the article presents advantages and disadvantages of distance learning in the conditions of a higher educational institution, as well as an assessment of prospects for the online education development both in the world and in Russia.
\end{abstract}

Keywords-information society, distance learning, e-learning, Internet technologies, educational platforms for online learning

\section{INTRODUCTION}

Federal state educational standards of the new generation completely change the view of modern education as a whole. The law "On Education in the Russian Federation" in Articles 17 and 18 defines the implementation of educational programs using e-learning and distance learning technologies [1]. "The government carries responsibility for creating an enabling environment that encourages educational institutions to more widely use innovations and to be more responsive to needs of global competitive economy founded on knowledge, and changing demands of labor markets that require highly developed human capital".

Forming a digital educational environment is a key condition to train personnel for the digital economy. This problem is supposed to be solved within the priority national project Modern Digital Educational Environment in the Russian Federation included into the national project Education [2].

The project is aimed at improving accessibility, relevance and quality of education due to using modern online technologies as well as the potential of leading higher educational institutions of the country, educational online platforms, and business solutions. According to the document, by the end of 2025 in Russia there will be 11 million learners which will take online courses on the Open Education platform. For these purposes, it is planned to organize an Internet portal for online courses, integrated with the Unified Identification and Authentication System (ESIA) and the Contingent GIS (geographic information system), as well as to test the system for assessing the quality of the knowledge gained. In total there will be 3.5 thousand online courses within the project. Also, a norm and law base will be developed which will regulate legally the mastering of online courses on the Portal and assign them to educational programs. 
When studying the problem of distance learning development, it should be especially noted the impact of COVID-19 on higher education. The pandemic put universities in difficult conditions to which they had to adapt as soon as possible. A lot of problems and questions arose: what forms and means of distance learning are to be used, what are the ways of assessing the knowledge gained, how the state final certification and recruitment for the next year are to be carried out.

Also, the pandemic negatively affected the international cooperation in the field of education and science: international travels were cancelled, programs of exchange and academic mobility of students and scientific and pedagogical personnel were suspended, many programs in the line of research cooperation were paused.

So, the problem of online education development is relevant now as it was never before.

\section{RESEARCH METHODS}

Methodological basis of the research was a comprehensive approach based on the principle of theory and practice unity, which includes modern methods of social and economic analysis, namely, evolutionary, systemic, structural and functional, comparative, and sociologic ones.

\section{RESEARCH RESULTS}

For the first time, distance education in Russia was referred to in the early 90s. In 1995 the Concept for Creation and Development of a Unified System of Distance Education in Russia was adopted which formulated an important provision about "high social significance of distance education, existing demands in it, and availability of needed pedagogical, scientific and technical, methodical potentials, and financial possibilities".

The following foreign and domestic scientists studied the general theoretical and methodological problems of using distance learning technologies at different educational levels: A. V. Gustyr, E. S. Polat [3], A. A. Andreev, M. P. Karpenko [4], A. A. Akhayan [5], O. A. Lavrov, D. Kigan, G. Daniel, at al. Authors suggested different points of view, describing the system of distance education. They have different opinions about distance learning functions, principles, methods, educational means, etc.

Here are some of the most common definitions of distance learning.

The Open Russian Education Portal gives the following definition of distance learning: "this is a form of education at which a teacher and students are physically separated in time and/or space, which differs from extramural courses in terms of the use of distance technologies".

A group of specialists from the Moscow State University of Economics, Statistics and Informatics considers the distance education as "a technology of distance learning at which a teacher and students are physically located in different places and use case, television and network technologies in their educational process".

The United States Distance Learning Association (USDLA) understands the distance learning as a process of education, in which all participants are largely separated, that is why they use interactive electronic means. In the opinion of experts, self-control prevails over the teacher's control in this type of education.

The main goal of distance education is to overcome place and time barriers. Students can live in isolated rural regions without access to education. Other students can have free access to the college, but the college can lack the educational course the students need. Distance learning allows those who cannot physically attend full-time courses to receive education. In addition, time becomes a valuable resource when students try to balance family, work and education. A trip to the university, spending time at the university at the appointed (probably, inconvenient) time may not fit into the student's overall schedule. Distance learning courses increasingly allow students to participate at a time most appropriate for them [6].

The theoretical analysis showed that there was no a single opinion about the definition of the term "distance learning". In our opinion, distance learning is primarily a newest form of education which, in many countries, co-exists with other forms of education such as full-time education, correspondence education, extracurricular education. One of characteristics of this kind of education is a geographic remoteness (distance). Second characteristic of this kind of education is the use of modern information telecommunication technologies in the educational process. The chief characteristic of distance learning is interactivity, a constant systematic interaction between all participants in the educational process, firstly, between the teacher (or, the so-called, tutor) and students, secondly, between students and, thirdly, between the student and the educational materials. So, interactivity in distance learning is implemented at the level of interaction between the teacher and students, and at the level of interaction between students and their educational aids, predominantly, electronic ones $[7,8]$.

The use of information technologies in the organization of the higher educational process is an indispensable condition for the activities of modern universities.

In the world, this work has been carried out for a long time and is actively used in the education systems of the USA and European countries.

European countries are leaders in the field of distance elearning. There distance learning dates back to the $70 \mathrm{~s}$ of the 20th century.

The leading European countries in the field of developing and improving e-education are Germany, Spain, Italy, Finland, Sweden, France, Czech Republic, Great Britain.

Thus, in Great Britain the Open University unites 305 centers of more than 40 countries. The US National University of Technology uses over 300 training sites in 46 universities [9].

Educational program for adults includes courses in science, business, management. DE National University (UNED) in Spain has been functioning for over 20 years. It includes 58 domestic training centers and 9 centers abroad [10].

Distance education demand is growing, this growth is due to the fact that a modern person has less time and more business with every passing day. Given that we live in the age of digital technologies development, the education sector should also develop, in order to train personnel ready to work and develop 
digital technologies, and be more flexible, able to adapt to rapidly changing conditions in the world. So, in the education sector there constantly arise innovations which allow a person to gain much more knowledge with a minimum amount of time, study and master any technology with the help of distance education, thereby saving time that a person, for example, spends on the road.

According to the latest data, today there are several hundred free and commercial learning environments that support eeducation. The most common are Yo-Stadi, ATutor, Claroline, Dokeos, LAMS, Blackboard, OLAT, OpenACS, iSpringOnline, TalentLMS, Inkling, Moodle, Sakai, Versal, WebTutor, etc.

Distribution of mass market shares for e-education (EE) platforms is shown in Fig. 1.

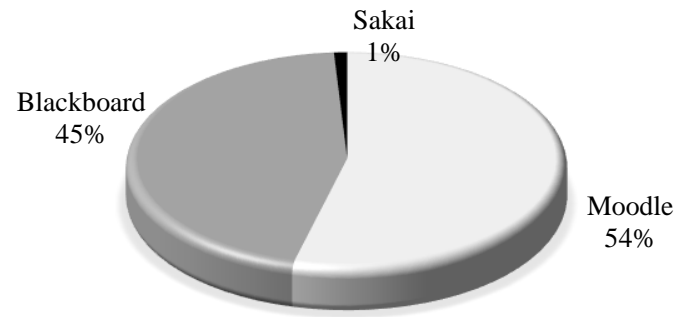

Fig. 1. Distribution of market shares for EE platforms

In fact, market shares occupied by different platforms greatly vary depending on the country and the field of application, however, the results of systemic comparison will show an approximate picture of offered market solutions which will allow us to conclude about the relevance of the given rating situation.

The Blackboard EE platform is a set of programs designed to implement e-education and create training courses. This is a highly developed hard- and software. This product is commercial (property of BlackboardInc Company) and possesses a closed source. The vast majority of American educational institutions use this platform for e-learning.

Sakai Distance Learning System is an open source software environment demanded by academic communities, commercial organizations and individuals. Sakai possesses a free license and is used for teaching, scientific research, collaboration, etc. A number of the largest universities of the world, including leaders in the field of information technologies, are developing and using this platform to create support systems for network and distance learning. Among the largest universities using Sakai there are Stanford University, University of Michigan, California-Berkeley, Yale University and others [11].

The Moodle System (Modular object-oriented dynamic learning environment) is one of the most powerful and common environments of e-education among systems of distance learning offered on the market today. The Moodle is distributed free of charge as open source software under GNU Public License (rus).

The popularity of this tool can be estimated according to the statistics on the official website of the project:

- about 100000 registered educational sites;
- the number of users is approaching 130 million;

- the number of created courses exceeds 14800000 ;

- $\quad$ is used in 232 countries.

When using the Moodle, it is possible to effectively organize and monitor the work of students. Teachers and methodologists can track the dynamics and learning progress of students. The System shows which elements of the course have already been passed, and which ones have yet to be completed. The student can track his/her learning progress estimated in per cent in his/her personal account [12].

The conducted comparative analysis of the leading platforms showed that the Moodle platform is of the greatest interest among the EE platforms, since its application is not limited to any one program, but forms a special educational sphere, suitable not only for interaction between a teacher and students, but also for support full-time forms of education. Also it may be used to organize and conduct regular distance courses, in addition the Moodle System is free [13].

In May 2020, the All-Russian Center for the Study of Public Opinion (VTsIOM) conducted a survey among university students regarding changes in the level of workload, the quality of education and the possible consequences of switching to a remote learning format.

An increase in the workload on teachers was noticed by $55 \%$ of the students surveyed by VTsIOM. One in five (20\%) says that the workload on teachers has remained the same as in the traditional teaching mode. In addition, according to the opinion of every second student $(51 \%)$, the workload on students has also increased.

Speaking about the level of distance teaching, more than half of the students $(53 \%)$ rated it as high or rather high. Only $12 \%$ of the students rated it as low. The majority of the students are satisfied with the way distance education is organized at their university in the conditions of COVID-19 spreading. This was reported by $72 \%$, with one in four reporting extreme satisfaction. $26 \%$ of the students reported that the distance education was organized unsatisfactorily in some degree [14].

In the same period, RAEX Rating Agency carried out a survey about pros and cons of distance education practice, in which more than 6000 students from 153 universities of Russia participated.

At the same time, over $70 \%$ of the questioned students complained of the lack of face-to-face communication with their mates and teachers during distance learning, 36,9\% of young people admitted that it was hard for them to organize their work. In addition, $33.8 \%$ reported such a shortcoming as a curtailed training format, in which there are no laboratory and practical works.

Among the pros of distance learning, more than half of the respondents named the opportunity to plan their time and improve their independent work skills. More than $90 \%$ of the interviewed students point out the electronic correspondence with teachers among the most accessible formats of distance learning. In a virtual personal account, $75.3 \%$ of students receive assignments, $72.3 \%$ complete interactive assignments (tests, polls, etc.). More advanced formats, such as attending video seminars, are available to less than $70 \%$ of students. 
In addition, $58.1 \%$ of the surveyed students of Russian universities expressed dissatisfaction with the work of equipment during distance learning. Communication problems, low functionality of applications, interruptions in the operation of resources were reported by $47 \%$ of the students surveyed in the capital, in the regions $-71.2 \%$ of respondents. Only $13.6 \%$ of the students were fully satisfied with technical solutions [15].

Thus, based on the results of the above surveys, we will highlight the advantages and disadvantages of introducing distance learning. The evident advantages are the following (Fig. 2)

- Mobility. Distance learning allows students to learn from any place where there is a stable access to the Internet. Also, they can study at any time convenient for them. All of this facilitates the learning process for people living in different time zones, as well as allows students to combine online education with work or higher education. Besides, students can schedule their time more effectively. For example, you might learn something on the bus ride home, or while exercising at the gym. This means that even the busiest students might study properly.

- Differentiation: opportunity to work out certain parts of educational material and independently select the way of learning taking into account abilities, level, preferences of students.

- Opportunity of self control.

- Opportunity to interact more with the teacher.

- Rapid introduction of knowledge, instant update of information, accessibility.

- Use of new technologies increases the motivation of students [16]

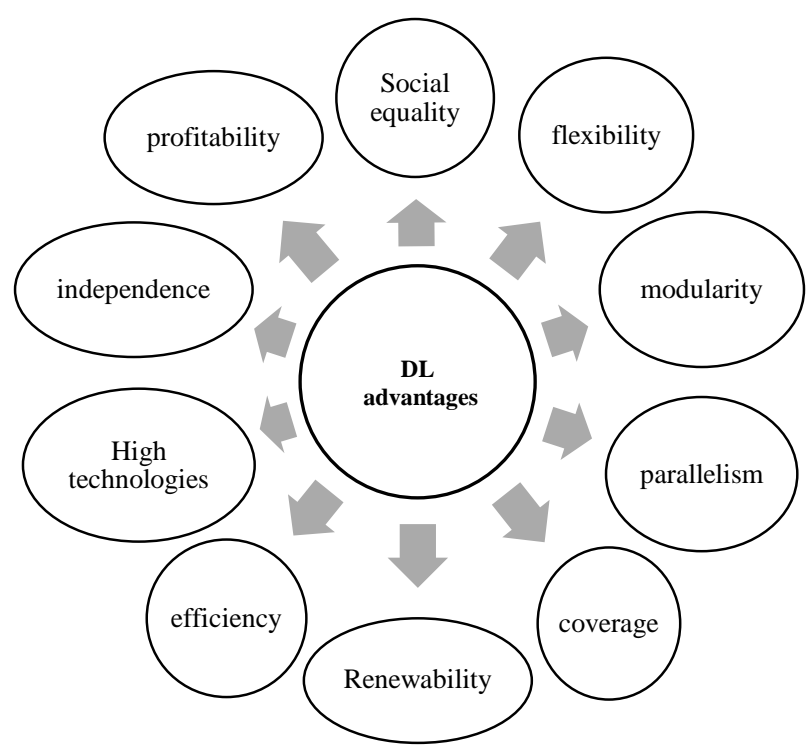

Fig. 2. Advantages of distance learning (DL)

In addition, those students which are ill, injured, disabled, unable to attend classes can receive education due to online attendance.

Interaction with teachers is much more effective in online environment compared with traditional environment. Through technologies and direct contact, students can communicate and interact with their teachers day and night. Often teachers allow students to send them text or instant messages with questions on tasks or exams. Thanks to the use of the most modern ways of communication, interactivity between students and teachers is at a record-high level [17].

However, despite all the advantages, the emergency transition to distance learning caused by the spread of Covid-19 resulted in a number of interrelated problems

Certain countries were unable to switch to online learning due to a variety of reasons, including the lack of equipment at universities, insufficient coverage of the Internet, low quality of life, etc.

There are problems with applications for video communication needed to conduct lectures or seminars. University websites can be unstable due to overloading on university information systems caused by a large flow of students [18].

In addition, teachers do not have sufficient knowledge in the field of distance learning, they are not aware of available eeducation platforms, their functionality, effective methods of online teaching, etc.

Foreign students found themselves in a difficult situation. Due to closed boarders and cancelled flights, many foreign students were unable to return home, while others, on the contrary, could not arrive for training, In addition, in many countries there is a problem to attend foreign online courses, as they are blocked or limited in time. Some students met financial problems as they were unable to find job, etc.

\section{DISCUSSION AND CONCLUSIONS}

Summing up the analysis of the development of distance education in Russia and in the world, we note the following

Numerous researches in the field of distance learning have shown that the elements of distance technologies when properly applied influence positively the labor intensity of teaching staff, the efficiency of students' learning, thereby improving education results and quality of teaching.

But it should be considered that the use of distance technologies can lead to a number of negative consequences. In particular, they can lead to minimization of social contacts and excess individualization which result in the lack of living educational communication between teachers and students, students and students, substituting it with "a dialogue with a computer".

Tools of distance learning if applied improperly can contribute to the formation of stereotyped thinking, formal and non-initiative attitude to activities, etc. In addition, the excessive use of information tools can impact the health of all participants in the education process.

The use of distant technologies using "the more, the better" principle cannot lead to a real improvement of educational process. No technology can replace the work of a teacher but it can make this work more effective and interesting, provided there is a balanced and well reasoned approach.

Distance learning can become an excellent addition to the traditional process of education, as it makes it more diverse, and 
allows students from all over the world to gain additional knowledge in certain disciplines. However, it is important to develop both types of educational technologies equally, learn how to combine them in the most effective way, in order to get the best results.

\section{References}

[1]. Federal Law No. 273-FZ of December 29, 2012 "On Education in the Russian Federation". (In Russ.).

[2]. The priority project in the field of education "Modern digital educational environment in the Russian Federation" was approved by the Government of the Russian Federation on October 25, 2016 as part of the implementation of the state program "Development of education" for 2013-2020. (In Russ.). Retrieved from http://government.ru/projects/selection/643

[3]. E.S. Polat, M.Yu. Bukharkina, M.V. Moiseeva, and A.E. Petrov, "New pedagogical and information technologies in the education system" [Novyye pedagogicheskiye i informatsionnyye tekhnologii $\mathrm{v}$ sisteme obrazovaniya], Moscow: Publishing center "Akademiya", 2009.

[4]. O.M. Karpenko, M.D. Bershadskaya, and Yu.A. Voznesenskaya, "The role of mega-universities in the development of distance education" [Rol' megauniversitetov v razvitii distantsionnogo obrazovaniya], Proceedings of the Modern Academy of Humanities, 2008, vol. 8, pp. 36-54.

[5]. A.A. Akhayan, and V.V. Laptev, "On the concept of the distance pedagogical education system" [O kontseptsii sistemy distantsionnogo pedagogicheskogo obrazovaniya], Pedagogical education in Altai, 1999, vol. 1, pp. 377-378.

[6]. "Online learning: how it is changing the structure of education and university economics. Open discussion Ya.I. Kuzminov - M. Karnoy" [Onlayn-obucheniye: kak ono menyaet strukturu obrazovaniya i ekonomiku universiteta. Otkrytaya diskussiya Ya. I. Kuzminov - M. Karnoy] // Education Issues , 2015, vol. 3, pp. 8-43. DOI: 10.17323/18149545-2015-3-8-43

[7]. G.A Reznik, and M.A. Kurdova, "Functions of the Russian university in the conditions of formation of an innovation-oriented economy" [Funktsii rossiyskogo universiteta $\mathrm{v}$ usloviyakh formirovaniya innovatsionnoorientirovannoy ekonomiki], Integration of Education, 2017, vol. 21(3), pp. 441-458. (In Russ.). DOI: 10.15507/1991-9468.088.021.201703.441458

[8]. Digitalization as a priority direction of modernization of Russian education [Tsifrovizatsiya kak prioritetnoye napravleniye modernizatsii rossiyskogo obrazovaniya: monografiya], in: N.V. Gorbunova (Ed.), Saratov, 2019, pp. 44-66.

[9]. I. Aidrous, and R.R. Asmyatullin, "World experience of using distance education technologies" [Mirovoy opyt ispol'zovaniya tekhnologiy distantsionnogo obrazovaniya // Vysshee obrazovaniye v Rossii], Higher education in Russia, 2015, vol. 5, pp. 139-145. (In Russ.). Retrieved from https://cyberleninka.ru/article/n/mirovoy-opyt-ispolzovaniya-tehnologiydistantsionnogo-obrazovaniya

[10]. A.Kh. Braliev, "World information technologies in the education system" [Mirovye informatsionnye tekhnologii $\mathrm{v}$ sisteme obrazovaniya], Bulletin of RUDN University. Series: Informatization of education, 2009, vol. 2, pp. 25-30. (In Russ.). Retrieved from https://cyberleninka.ru/article/n/mirovye-informatsionnye-tehnologii-vsisteme-obrazovaniya

[11]. S.A. Krasko, L.G. Sergeeva, and N.N. Mikhaylova," Application of distance learning in technical universities" [Primeneniye distantsionnogo obucheniya v tekhnicheskikh universitetakh], Higher education in Russia, 2018, vol. 6, pp. 135-139. (In Russ.). Retrieved from https://cyberleninka.ru/article/n/primenenie-distantsionnogoobucheniya-v-tehnicheskih-universitetah

[12]. U.S. Zakharova, and T.I. Tanasenko, "MOOC in higher education advantages and disadvantages for teachers" [MOOK $\mathrm{v}$ vysshem obrazovanii: dostoinstva i nedostatki dlya prepodavateley], Education Issues, 2019, vol. 3, pp. 176-202. (In Russ.). Retrieved from https://cyberleninka.ru/article/n/mook-v-vysshem-obrazovaniidostoinstva-i-nedostatki-dlya-prepodavateley

[13]. V.P. Tikhomirov, V.I. Soldatkin, S.L. Lobachev, and O.G. Kovalchuk, "Distance learning: to virtual environments of knowledge (part 1)" [Distantsionnoye obucheniye: $\mathrm{k}$ virtual'nym sredam znaniy (chast' 1)], Open Education, (In Russ.). Retrieved from http://www.ejoe.ru/sod/99/2_99/st158.html

[14]. Official website of the All-Russian Public Opinion Research. (In Russ.). Retrieved from http://www.wciom.ru

[15]. Ö.H. Kuzu, "Digital transformation in higher education: a case study on strategic plans", Higher education in Russia, 2020, vol. 3, pp. 9-23. DOI: https://doi.org/10.31992/0869-3617-2019-29-3-9-23

[16]. A. Tait, "Distance and E-Learning, Social Justice, and Development: The Relevance of Capability Approaches to the Mission of Open Universities", The International Review of Research in Open and Distributed Learning, 2013, vol. 14(4).

[17]. O.V. Usacheva, and M.K. Chernyakov, "Assessment of the readiness of universities for the transition to a digital educational environment" [Otsenka gotovnosti vuzov $\mathrm{k}$ perekhodu $\mathrm{k}$ tsifrovoy obrazovatel'noy srede], Higher education in Russia, 2020, vol. 5, pp. 53-62. (In Russ.) DOI: https://doi.org/10.31992/0869-3617-2020-29-5-53-62

[18]. A.S. Al-Adwan, A. Al-Madadha, and Z. Zvirzdinaite, "Modeling Students Readiness to Adopt Mobile Learning in Higher Education: An Empirical Study", The International Review of Research in Open and Distributed Learning, 2018, vol. 19(1). 